\title{
Charakter prawny odmowy przyznania środków z Europejskiego Funduszu Rolnego na rzecz Rozwoju Obszarów Wiejskich
}

1. Niniejsze opracowanie stanowi próbę oceny wybranych rozwiązań proceduralnych wprowadzonych przez ustawę z dnia 7.03.2007 r. o wspieraniu rozwoju obszarów wiejskich z udziałem środków Europejskiego Funduszu Rolnego na rzecz Rozwoju Obszarów Wiejskich. ${ }^{1}$ W szczególności rozważania dotyczą zaproponowanych przez ustawodawcę dwóch odmiennych trybów postępowania w sprawach o przyznanie środków z EFRROW, z uwzględnieniem - spornego zarówno w doktrynie, jak i orzecznictwie - charakteru prawnego aktu odmowy przyznania środków $\mathrm{z}$ funduszu.

Analiza została przeprowadzona przy uwzględnieniu zmian wprowadzonych do polityki rozwoju obszarów wiejskich w okresie programowania 2007-2013 oraz specyfiki postępowania w sprawie przyznania środków z funduszu.

W okresie programowania 2007-2013 w polityce rozwoju obszarów wiejskich nastąpiła zasadnicza reforma ${ }^{2}$. Jej normatywnym wyrazem są: rozporządzenie Rady (WE) nr 1290/2005 z 21.06.2005 r. w sprawie finansowania wspólnej polityki rolnej $^{3}$ oraz rozporządzenie Rady (WE) nr 1698/2005 z 20.09.2005 r. w sprawie wsparcia rozwoju obszarów wiejskich przez Europejski Fundusz Rolny na Rzecz Rozwoju Obszarów Wiejskich ${ }^{4}$. Reformę WPR postrzegać należy w szerszym kontekście reformy Polityki Spójności. Polegała ona między innymi na wyłączeniu Wspólnej Polityki Rolnej oraz Wspólnej Polityki na rzecz Rybołówstwa poza Politykę Spójności. Dla państw członkowskich oznaczało to potrzebę stworzenia mechanizmów koordynacji instrumentów tych polityk z polityką strukturalną w celu zapewnienia trwałego rozwoju gospodarczego kraju, w tym rozwoju obszarów wiejskich. Koordynacja dotyczyła przede wszystkim określenia zakresu wsparcia w ramach progra-

\footnotetext{
1 Ustawa z dnia 7.03.2007 r. o wspieraniu rozwoju obszarów wiejskich z udziałem środków Europejskiego Funduszu Rolnego na rzecz Rozwoju Obszarów Wiejskich, Dz.U. Nr 64, poz. 427, dalej zwana u.w.r.o.w.

2 Por. E. Tomkiewicz, Polityka rozwoju obszarów wiejskich na lata 2007-2013 (perspektywy na tle dotychczasowej ewolucji ustawodawstwa), Studia luridica Agraria 2007 r., t. 6, s. 23 i n.

3 Dz.Urz. UE 2005 L 209/1.

4 Dz.Urz. UE 2005 L $277 / 1$.
} 
mów finansowanych z instrumentów strukturalnych oraz z Europejskiego Funduszu Rolnego na rzecz Rozwoju Obszarów Wiejskich (dalej EFRROW) i Europejskiego Funduszu Gwarancji (dalej EFRG). Potrzeba koordynacji widoczna jest również na poziomie krajowej ustawy kompetencyjnej u.w.r.o.w. w zakresie zadań i właściwości organów i jednostek organizacyjnych oraz trybu przyznawania, wypłaty i zwracania pomocy finansowej.

Inne zasady zreformowanej WPR, o podstawowym znaczeniu dla rozwoju obszarów wiejskich polegały na uproszczeniu finansowania. Na mocy rozporządzenia nr 1290/2005 utworzone zostały dwa fundusze: Europejski Fundusz Rolny Gwarancji, z którego finansowane są instrumenty wsparcia i ochrony rynku rolnego oraz Europejski Fundusz Rolny na Rzecz Rozwoju Obszarów Wiejskich, przeznaczony na wsparcie rozwoju obszarów wiejskich. Ponadto przewidziano strategiczne podejście do problematyki rozwoju obszarów wiejskich, co polega na doborze prawnych instrumentów polityki wiejskiej przyjętych w Programie Rozwoju Obszarów Wiejskich zbieżnych z priorytetami krajowymi ujętymi w Krajowym Planie Strategicznym oraz priorytetami wspólnotowymi wyrażonymi w Strategicznych Wytycznych Wspólnoty.

Instrumenty prawne wsparcia przewidziane zostały w jednym dokumencie: Programie Rozwoju Obszarów Wiejskich na lata 2007-2013, który połączył w sobie instrumenty przewidziane w okresie programowania 2004-2006 w dwóch niezależnych od siebie i wzajemnie uzupełniających się dokumentach programowych. Był to Sektorowy Program Operacyjny - Restrukturyzacja i modernizacja sektora żywnościowego oraz rozwój obszarów wiejskich, współfinansowany z Sekcji Orientacji EFOiGR (był elementem Narodowego Planu Rozwoju na lata 2004-06) oraz Plan Rozwoju Obszarów Wiejskich na lata 2004-06, współfinanowanym z Sekcji Gwarancji EFOiGR. Ponadto inne Sektorowe Programy Operacyjne oraz Zintegrowany Program Operacyjny Rozwoju Regionalnego zawierały działania wspierające szeroko rozumiany rozwój obszarów wiejskich.

Zmianom o charakterze konsolidacyjnym, polegającym na połączeniu w jednym dokumencie programowym wszystkich instrumentów wsparcia rolnictwa i rozwoju obszarów wiejskich, nie towarzyszą zmiany polegające na ujednoliceniu i uproszczeniu procedury pozyskiwania przez beneficjentów środków finansowych. Postępowanie w sprawie przyznania pomocy ze środków EFRROW i EFRG ma w prawodawstwie unijnym charakter uproszczonego systemu przyznawania świadczeń, kontroli warunków ich uzyskania i wykorzystania. Taki charakter powinien zostać nadany również postępowaniu w sprawie przyznania pomocy w krajowej ustawie kompetencyjnej - (u.w.r.o.w.), określającej zadania oraz właściwość organów i jednostek organizacyjnych oraz warunki i tryb przyznawania, wypłaty oraz zwracania pomocy finansowej. Polski ustawodawca nie zrealizował tak postawionego postu- 
latu i w ustawie z 7.03.2007 r. o wspieraniu rozwoju obszarów wiejskich z udziałem środków Europejskiego Funduszu Rolnego na rzecz Rozwoju Obszarów Wiejskich utrzymał w zakresie przyznawania pomocy ze środków unijnych dwa odrębne tryby, powielając tym samym rozwiązania proceduralne obowiązujące w okresie 2004-06. W ramach PROW pomoc przyznawana była na podstawie ustawy z dnia 28 listopada 2003 r. o wspieraniu rozwoju obszarów wiejskich ze środków pochodzących z Sekcji Gwarancji Europejskiego Funduszu Orientacji i Gwarancji Rolnej - w drodze decyzji administracyjnej, natomiast w przypadku działań objętych SPO RiMSŻiROW podstawą prawną pomocy była ustawa z dnia 20 kwietnia 2004 r. o Narodowym Planie Rozwoju ${ }^{5}$, a pomoc udzielana była na podstawie umowy, poprzedzonej decyzją administracyjną o przyznaniu środków.

2. Ustawa z dnia 7.03.2007 r. o wspieraniu rozwoju obszarów wiejskich z udziałem środków Europejskiego Funduszu Rolnego na rzecz Rozwoju Obszarów Wiejskich przewiduje dwa tryby postępowania w sprawie przyznania pomocy.

W pierwszym przypadku pomoc przyznawana jest po przeprowadzeniu postępowania w indywidualnej sprawie, kończącego się wydaniem decyzji administracyjnej. W postępowaniu tym regulowane są stosunki administracyjnoprawne, przy czym postępowanie to mieści się w pojęciu indywidualnej sprawy z zakresu administracji publicznej, a rozstrzygnięcia merytoryczne zapadają w formach władczych przewidzianych w postępowaniu administracyjnym. Do postępowań tych stosuje się przepisy k.p.a., o ile przepisy powołanej ustawy nie stanowią inaczej. Przepisy procesowe zawarte w u.w.r.o.w. mają zatem charakter nieautonomiczny. Regulują tylko najważniejsze, charakterystyczne dla danego postępowania zagadnienia procesowe, a w pozostałych sprawach odsyłają do przepisów ogólnych, uregulowanych w k.p.a. ${ }^{6}$ Tryb ten dotyczy działań objętych w poprzednim okresie programowania PROW 2004-2006. ${ }^{7}$

Z uwagi na dużą liczbę beneficjentów, ustawodawca zastosował w tym zakresie rozwiązania proceduralne, będące pewnymi modyfikacjami przepisów k.p.a., mające usprawnić, uprościć i przyspieszyć postępowanie w sprawie przyznania pomocy,

Dz.U. Nr 116, poz. 1206 z późn. zm.

6 Na postępowania administracyjne autonomiczne oraz nieautonomiczne zwrócił uwagę J. Borkowski, Postępowanie administracyjne ogólne a szczególne, (w:) Księga pamiątkowa Profesora E. Ochendowskiego, Toruń 1999, s. 103.

7 Dotyczy to następujących działań: ułatwienie startu młodym rolnikom; renty strukturalne; poprawienie i rozwijanie infrastruktury związanej z rozwojem i dostosowaniem rolnictwa i leśnictwa poprzez: scalanie gruntów, gospodarowanie rolniczymi zasobami wodnymi; uczestnictwo rolników w systemach jakości żywności; wspieranie gospodarstw rolnych niskotowarowych w fazie restrukturyzacji; grupy producentów rolnych; korzystanie z usług doradczych przez rolników i posiadaczy lasów; wspieranie gospodarowania na obszarach górskich i innych obszarach o niekorzystnych warunkach gospodarowania; płatności dla obszarów natura 2000 oraz związanych z wdrożeniem Ramowej Dyrektywy Wodnej; program rolnośrodowiskowy; zalesianie gruntów rolnych oraz zalesianie gruntów innych niż rolne. 
jednocześnie aktywizując strony tego postępowania ${ }^{8}$. Szczególnie istotną regulację ustawodawca wprowadził w art. 21 u.w.r.o.w. Polega ona między innymi na:

- zastosowaniu rozkładu ciężaru dowodowego ugruntowanego w prawie cywilnym (art. 21 u.w.r.o.w.),

- rezygnacji z obowiązku wyczerpującego zebrania całego materiału dowodowego przez organ administracji i ograniczenie go do obowiązku rozpatrzenia materiału dowodowego zebranego w aktach sprawy,

- obowiązek zapewnienia stronom, ale tylko na ich żądanie, czynnego udziału w każdym stadium postępowania oraz obowiązek udzielenia stronom niezbędnych pouczeń co do okoliczności faktycznych i prawnych, które mogą mieć wpływ na ustalenie ich praw i obowiązków będących przedmiotem postępowania.

Oprócz częściowego odejścia od zasad przewidzianych w k.p.a., w postępowaniu w sprawie przyznania środków z EFRROW ustawodawca wprowadził szereg innych, znacznie mniej doniosłych rozwiązań proceduralnych, jak choćby wprowadzenie dwumiesięcznego terminu rozpatrywania odwołań od decyzji czy możliwość zmiany ostatecznej decyzji, na mocy której strona nabyła prawo, również bez zgody strony, jeżeli nie ograniczy to nabytych przez nią praw. Z uwagi na ramy niniejszego opracowania, omówienie szczegółowe wskazanych rozwiązań proceduralnych zostanie pominięte. Przyjęte rozwiązania budzą jednak szereg wątpliwości w procesie stosowania prawa przez organy administracji i sądy administracyjne. W obecnym okresie programowania 2007-2013 zostaną one zapewne wyjaśnione w praktyce orzeczniczej.

Podstawową wątpliwość budzi natomiast utrzymanie różnych trybów postępowania w sprawie przyznania pomocy, pomimo licznych wątpliwości zgłaszanych w procesie legislacyjnym, uzasadnianych rodzajem działań, w ramach których beneficjentom udzielane jest wsparcie ${ }^{9}$. Ostatecznie, w przypadku działań, które nie mają charakteru inwestycyjnego i nie wymagają udziału środków własnych rolników, zastosowanie ma procedura administracyjna przyznawania pomocy przewidziana przepisami k.p.a., z zastosowaniem pewnych rozwiązań szczególnych. Ustawodawca zdecydował się zatem na zastosowanie uproszczonego systemu przyznawania pomocy, wypłaty oraz jej zwracania.

3. Druga przewidziana ustawą procedura przyznawania środków ma charakter cywilnoprawny, co oznacza, że pomoc przyznawana jest na podstawie umowy

Ustawa o płatnościach w ramach systemów wsparcia bezpośredniego zawiera identyczna regulację, por. D. Łobos-Kotowska, Płatności do gruntów rolnych i płatność cukrowa - wybrane zagadnienia proceduralne, Przegląd Prawa Rolnego 2007, nr 2, s. 109 i n oraz J. Bieluk, D. Łobos-Kotowska, Komentarz do ustawy o płatnościach w ramach systemów wsparcia bezpośredniego, Warszawa 2008, komentarz do art. 3. 
zawieranej przez instytucję wdrażającą i beneficjenta, a źródłem zobowiązania jest czynność o charakterze administracyjnoprawnym. Do postępowań w sprawach przyznania pomocy na podstawie umowy nie stosuje się przepisów k.p.a., z wyjątkiem przepisów dotyczących właściwości miejscowej organów, wyłączenia pracowników organu, doręczeń i wezwań, udostępniania akt, a także skarg i wniosków. Tryb ten ma zastosowanie do działań, które stanowią kontynuację instrumentów wdrażanych w poprzednim okresie programowania w ramach SPO RiMSŻiROW z udziałem środków funduszy strukturalnych.

Przepisy powołanej ustawy wskazują w tym zakresie na istnienie dwóch wyraźnie wyodrębnionych etapów postępowania w sprawach dotyczących finansowania z publicznych środków wspólnotowych. W początkowym etapie, na wniosek podmiotu ubiegającego się o środki, wszczynane jest postępowanie, które kończy się przyznaniem lub odmową przyznania pomocy przez podmiot wdrażający. Rozstrzygnięcie podejmowane w pierwszym etapie stanowi przesłankę do zawarcia umowy, albo odmowy zawarcia umowy ${ }^{10}$. Drugi etap następuje po pozytywnym dla strony rozstrzygnięciu, polegającym na przyznaniu pomocy i polega na zawarciu umowy, określającej warunki jej uzyskania. Wnioskodawcę, który nie spełnia warunków przyznania pomocy, pomiot wdrażający informuje, w formie pisemnej, o odmowie przyznania pomocy, z podaniem przyczyn odmowy.

Kontrowersje prawne wzbudza charakter i forma prawna czynności poprzedzającej zawarcie umowy cywilnoprawnej. Nie jest on rozumiany jednolicie ani przez doktrynę, ani przez orzecznictwo. Spór w tym zakresie powstał na tle innych uregulowań prawnych ${ }^{11}$, jednak rozbieżność poglądów przedstawicieli judykatury, pozostaje aktualna na podstawie przepisów u.w.r.o.w. Wątpliwości dotyczą charakteru prawnego rozstrzygnięcia o odmowie przyznania środków. Rozważenia wymaga, czy odmowa ma charakter czynności cywilnoprawnej, czy też jest to czynność o charakterze administracyjnoprawnym, która podlega kontroli sądu administracyjnego, a zatem, czy jest to decyzja administracyjna czy akt lub czynność, o których mowa w art. $3 \S 2$ pkt 4 p.p.s.a.

U.w.r.o.w. nie przesądza jednoznacznie tej kwestii, pomimo że w okresie obowiązywania ustawy z dnia 28 listopada 2003 r. o wspieraniu rozwoju obszarów

10 Tryb cywilnoprawny dotyczy następujących działań; szkolenia zawodowe dla osób zatrudnionych w rolnictwie i leśnictwie; modernizacja gospodarstw rolnych; zwiększenie wartości dodanej podstawowej produkcji rolnej i leśnej; działania informacyjne i promocyjne; odtwarzanie potencjału produkcji leśnej zniszczonego przez katastrofy oraz wprowadzenie instrumentów zapobiegawczych; różnicowanie w kierunku działalności nierolniczej; tworzenie i rozwój mikroprzedsiębiorstw; podstawowe usługi dla gospodarki i ludności wiejskiej; odnowa i rozwój wsi; wdrażanie lokalnych strategii rozwoju; wdrażanie projektów współpracy; funkcjonowanie lokalnej grupy działania.

11 Kwestia ta została podjęta przez SN w uchwale z dnia 25.04.1964 r., (III CO 12/64, OSPiKA 1/1965), rozstrzygającej zagadnienie wstępne na podstawie ustawy z dnia 28.05.1957 r. o sprzedaży przez Państwo domów mieszkalnych i działek budowlanych (Dz.U. Nr 31, poz. 132), kwestią tą zajął się także NSA, podejmując uchwałę w dniu 29.03.2006 r. (II GPS 1/2006, OSP 2006/11) , na podstawie przepisów ustawy z dnia 27.08.1997 r. o rehabilitacji zawodowej i społecznej oraz zatrudnieniu osób niepełnosprawnych (Dz.U. Nr 123, poz. 776 z późn. zm.). 
wiejskich ze środków pochodzących z Sekcji Gwarancji Europejskiego Funduszu Orientacji i Gwarancji Rolnej, kwestia ta również wywoływała spory w doktrynie i judykaturze. Charakter prawny czynności poprzedzających zawarcie cywilnoprawnej umowy, a w szczególności odrzucenia wniosku przez instytucję zarządzającą programem, był kilkakrotnie przedmiotem rozstrzygnięć sądów administracyjnych. W wyroku z dnia 8.06.2006 r., NSA uznał, że przyznanie dofinansowania lub odmowa przyznania dofinansowania następuje w drodze decyzji administracyjnej wydawanej na podstawie art. 26 ust. 2 ustawy o NPR. Wobec tego przyjął, że pismo Prezesa ARiMR odrzucające wniosek o dofinansowanie realizacji projektu to decyzja administracyjna podlegająca kontroli sądu administracyjnego ${ }^{12}$. Następnie NSA wielokrotnie potwierdzał to stanowisko ${ }^{13}$, choć odnotować należy także orzeczenie zawierające odmienną tezę, w którym NSA stwierdził, że przepisy ustawy o NPR nie zawierają materialnoprawnej podstawy do wydania decyzji administracyjnej w sprawach dotyczących przyznania dofinansowania projektu. Podstawą dofinansowania jest umowa zawarta pomiędzy beneficjentem a instytucją zarządzającą, wdrażającą lub pośredniczącą ${ }^{14}$.

Argumentów za pierwszym stanowiskiem - o cywilnoprawnym charakterze informacji o odmowie przyznania środków - dostarcza uchwała NSA z 29.03.2006 r. ${ }^{15}$ W uchwale tej, wydanej na podstawie ustawy z dnia 27.08.1997 r. o rehabilitacji zawodowej i społecznej oraz zatrudnieniu osób niepełnosprawnych ${ }^{16}$, Sąd uznał, że odmowa udzielenia prowadzącemu zakład pracy chronionej przez samorząd województwa pożyczki nie jest sprawą sądowoadministracyjną w rozumieniu art. $1 \mathrm{w}$ zW. $\mathrm{z}$ art. 3 p.p.s.a. Uzasadniając to stanowisko, Sąd wskazał na cywilnoprawny charakter zawieranych umów, na charakter podmiotu udzielającego wsparcia, który działa nie tylko w sferze prawa publicznego, ale także prywatnego, ma osobowość prawną, działa przez swoje organy. Sąd podkreślił także, że zawieranie umów jest domeną prawa cywilnego, a podejmowane w tym zakresie czynności mają charakter cywilnoprawny ${ }^{17}$. Stanowisko Sądu w tej sprawie, spotkało się z uzasadnioną krytyką. Do uchwały zdanie odrębne zgłosiło aż trzech sędziów ${ }^{18}$. Uznali oni, że rozpatrzenie wniosku beneficjenta przez organ administracji przed zawarciem umowy następuje w drodze decyzji administracyjnej. W glosie krytycznej do uchwały M. Szubiakowski również wskazał na administracyjny charakter aktu odmowy przyznania

Wyrok NSA z dnia 08.06.2006 r. II GSK 63/06, (Lex nr 188514).

Stanowisko takie wyraził też NSA m.in. w wyroku z dnia 7.09.2005 r., sygn. akt II GSK 116/05, w postanowieniu z dnia 16.11.2006 r., sygn. akt II GSK 189/06, WSA w Warszawie w wyroku z dnia 29.09.2006 r., sygn. akt IV SA/ Wa 1064/06, w postanowieniu z dnia 17.04.2007 r., sygn. akt IV SAB/Wa 7/07. Stanowisko wyrażone przez NSA we wskazanych orzeczeniach zostało następnie potwierdzone uchwałą składu 7 sędziów w dniu 22.02.2007 r., sygn. akt II GPS 3/06.

Wyrok NSA z dnia 20.09.2006 r., sygn. akt II GSK 95/06.

Uchwała NSA z dnia 29.03.2006 (II GPS 1/2006, OSP 2006/1).

Dz.U. Nr 123, poz. 776 z późn. zm.

Podobne stanowisko wyraził także A. Agopszowicz, (w:) A. Agopszowicz, Z. Gilowska, M. Taniewska-Peszko, Prawo samorządu terytorialnego w zarysie, Katowice 2001, s. 253.

Sędziowie NSA R. Hauser, A Kuba, J. Trzciński. 
pomocy, stwierdzając jednocześnie, że wybór beneficjenta lub odmowa przyznania środków jest czynnością faktyczną z zakresu administracji publicznej i jest poddana kontroli sądu administracyjnego ${ }^{19}$.

Konieczne staje się zatem rozważenie zasadności uznania odmowy przyznania pomocy, jako aktu administracyjnego: decyzji administracyjnej lub aktów lub czynności dotyczących uprawnień lub obowiązków wynikających z przepisów prawa. Dla oceny charakteru prawnego informacji o odmowie udzielenia pomocy istotne jest rozważenie, jakie warunki muszą zostać spełnione, aby przed zawarciem umowy można było wyróżnić sprawę administracyjną, w której rozstrzyga się władczo o zawarciu lub odmowie zawarcia umowy. Wydaje się, że rozstrzygające znaczenie ma to, czy przepisy ustawowe przyznają danemu organowi władcze kompetencje $\mathrm{w}$ fazie rozpatrywania wniosku, poprzedzającej zawarcie umowy. Istotne jest zatem ustalenie, czy podmiot wdrażający, którym jest ARiMR, samorząd województwa, ARR lub podmiot, któremu minister powierzył na podstawie umowy wykonywanie zadań, wyłoniony w trybie przepisów o zamówieniach publicznych, ma przyznane kompetencje do podejmowania aktów lub dokonywania czynności o charakterze administracyjnoprawnym, poprzedzających zawarcie umowy lub prowadzących do odmowy zawarcia umowy ${ }^{20}$. Wobec wyznaczenia ARiMR szczególnej roli - podmiotu wdrażającego - w odniesieniu do większości działań PROW konieczne jest określenie jej statusu prawnego w sferze administracyjnoprawnej.

Agencja nie jest organem administracji państwowej w ścisłym tego słowa znaczeniu, wykonuje jednak zadania z zakresu administracji publicznej. Ze względu na charakter tych zadań (wspieranie rozwoju obszarów wiejskich i produkcji rolnej) i charakter kompetencji nie można uznać, żeby ARiMR była w całym obszarze jej działania upoważniona do stosowania środków o charakterze władczym. Dlatego też należy traktować ją jako organ o charakterze funkcjonalnym w takim zakresie, $w$ jakim jest ona uprawniona do działania $w$ formach o charakterze władczym ${ }^{21}$. Działanie w charakterze władczym wynikać może z wyraźnego przepisu prawa lub pośrednio z charakteru wykonywanej czynności. Przepisem takim jest art. 10 ust. 1 ustawy z dnia 9.05.2008 r. o Agencji Restrukturyzacji i Modernizacji Rolnictwa ${ }^{22}$, mocą którego ustawodawca powierzył prezesowi Agencji, dyrektorom oddziałów regionalnych, kierownikom biur powiatowych wydawanie decyzji administracyjnych w zakresie określonym w odrębnych przepisach. Podstawy prawne do wydawania takich decyzji znajdują się w ustawie o utworzeniu ARiMR, ale także w in-

Tak też J. Jagoda, Uchwała organu jednostki samorządu terytorialnego jako czynność poprzedzająca zawarcie umowy cywilnoprawnej, (w:) Umowy w administracji, pod red. J. Bocia i L. Dziewięckiej-Bokun, Wrocław 2008, s. 560 . Status prawny Agencji Restrukturyzacji i Modernizacji Rolnictwa NSA określił m.in. w wyroku z dnia 8.06.2006 r., III GSK 63/06, (LEX nr 190550). Dz.U. Nr 98, poz. 634. 
nych aktach prawnych, w tym w u.w.r.o.w. Podstawę prawną do wydawania takich decyzji stanowi przepis art. 10 powołanej ustawy. Użyte w przepisie określenie „pomoc jest przyznawana" wskazuje na władczy charakter takiego rozstrzygnięcia, które może stanowić podstawę do zawarcia umowy ${ }^{23}$. Władczy charakter rozstrzygnięcia ARiMR zbliża go zatem swoim charakterem do decyzji administracyjnej, a nie aktów lub czynności dotyczących uprawnień lub obowiązków wynikających z przepisów prawa, o których mowa w art. $3 \S 2$ pkt 4 p.p.s.a. Rozróżnienie decyzji administracyjnej i innych aktów lub czynności można oprzeć na kryterium oświadczenia woli i oświadczenia wiedzy. Decyzja administracyjna jest oświadczeniem woli organu wykonującego administrację publiczną, inne zaś akty są oświadczeniem wiedzy, które potwierdza uprawnienia lub obowiązki. ${ }^{24}$ Odmowa udzielenia pomocy następuje w formie rozstrzygnięcia o charakterze jednostronnym, zewnętrznym, konkretnym $\mathrm{i}$ indywidualnym. Tym samym procedurę $\mathrm{w}$ zakresie odmowy przyznania pomocy należy uznać za sformalizowane postępowanie administracyjne, do którego nie stosuje się przepisów k.p.a., które kończy się rozstrzygnięciem, ze wskazaniem przyczyn odmowy i merytorycznym rozstrzygnięciem. Podmiot wdrażający jest takim rozstrzygnięciem związany od chwili doręczenia stronie.

Charakter prawny rozstrzygnięcia w sprawie odmowy przyznania pomocy nie współgra z przewidzianym przez ustawodawcę w art. 22 ust. 4 u.w.r.o.w. trybem zaskarżania na zasadach określonych dla aktów lub czynności, o których mowa w art. $3 \S 2$ pkt 4 p.p.s.a. Z jednej bowiem strony należy wziąć pod uwagę władczy charakter rozstrzygnięcia $\mathrm{w}$ sprawie przyznania lub odmowy przyznania pomocy, $\mathrm{z}$ drugiej natomiast, tryb zaskarżania przedmiotowego rozstrzygnięcia, przewidziany dla aktów lub czynności, wskazuje na taki właśnie charakter pisemnej informacji o odmowie przyznania pomocy. Wnioskodawca nie ma zatem możliwości wniesienia odwołania od przedmiotowego rozstrzygnięcia. Za niedopuszczalnością odwołania przemawia również wyłączenie stosowania przepisów k.p.a., z wyjątkiem przepisów dotyczących właściwości miejscowej organów, wyłączenia pracownika organu, doręczeń i wezwań, udostępniania akt, a także skarg i wniosków do postępowań w sprawach przyznania pomocy na podstawie umowy, prowadzonych przez podmioty wdrażające. Rozstrzygnięcie o odmowie przyznania pomocy podlega kontroli sądów administracyjnych. Skargę do WSA może wnieść wnioskodawca, po uprzednim wezwaniu na piśmie właściwego organu do usunięcia naruszenia prawa w terminie czternastu dni od dnia, w którym skarżący dowiedział się lub mógł się dowiedzieć o wydaniu aktu.

Nie przesądzając o charakterze prawnym informacji o odmowie przyznania pomocy, należy stwierdzić, że czynności o charakterze administracyjnoprawnym w przypadku innych działań natomiast w oparciu o kolejność zgłoszonych wniosków. 
w formie aktów lub czynności dotyczących uprawnień lub obowiązków wynikających z przepisów prawa (art. $3 \S 2$ pkt 4 p.p.s.a.) oraz w formie decyzji administracyjnej (art. $3 \S 2$ pkt 1 p.p.s.a.) nie różnią się w istotny sposób odnośnie do poziomu ochrony procesowej. Zarówno jedne, jak i drugie czynności podlegają kontroli sądu administracyjnego. Działanie w obu tych formach jest zaskarżalne do sądu administracyjnego, który realizuje kontrolę ich legalności, a zatem podmioty mające interes prawny doznają przed sądem pełnej ochrony procesowej ${ }^{25}$.

Przyjęcie stanowiska, że odmowa przyznania środków ma charakter aktu administracyjnego, pozostawia jeszcze jedną wątpliwość o skutki uchylenia takiego aktu przez sąd administracyjny. Podjęte rozważania dotyczą również skutków prawnych uchylenia aktu pozytywnego - o przyznaniu środków dla ważności umowy cywilnoprawnej. Stosownie do art. 146 § 1 p.p.s.a sąd, uwzględniając skargę, uchyla dany akt lub stwierdza jego bezskuteczność. Powołany przepis nie przewiduje natomiast stwierdzenia nieważności zaskarżonej odmowy przyznania środków ${ }^{26}$. Aby określić skutki wyroku uchylającego akt administracyjny, należy określić charakter tego aktu, a w szczególności ustalić stosunek względem cywilnoprawnej umowy.

Według stanowiska judykatury, wyrażonego w uchwale SN z 25.04.1964 r., rozstrzygnięcie o przyznaniu pomocy należy traktować jako przesłankę konieczną do zawarcia umowy i jej skuteczności. Przyznanie pomocy poprzedzone jest czynnościami przygotowawczymi zmierzającymi do ustalenia beneficjenta pomocy, jej wielkości, warunków uzyskania. Postulat prawidłowego wykorzystania środków publicznych wymaga szczególnej reglamentacji stadium przygotowawczego przy pomocy przepisów administracyjnych. Akt administracyjny nie jest jednak źródłem zobowiązania. Właściwym źródłem praw i obowiązków jest cywilnoprawna umowa. Późniejsze uchylenie aktu administracyjnego, po zawarciu na jego podstawie umowy, nie powoduje nieważności umowy, skoro jest ona w pełni samodzielną czynnością prawną z zakresu prawa cywilnego i podlega sankcjom prawa cywilnego przy ocenie jej ważności. Okoliczności, z powodu których uchylenie nastąpiło, mogą mieć oczywiście znaczenie dla oceny w świetle prawa cywilnego ważności umowy cywilnoprawnej lub dopuszczalności uchylenia się od skutków prawnych zawartego w niej oświadczenia woli ${ }^{27}$. Podobne stanowisko wyraził S. Breyer, który określił akt administracyjny poprzedzający zawarcie umowy cywilnoprawnej jako akt wewnętrzny, którego uchylenie nie wpływa na nieważność zawartej na jego podstawie umowy ${ }^{28}$.

E. Bojanowski, Glosa do wyroku WSA z dnia 14 kwietnia 2005 r., II SA/Gd 1646/03, GSP-Prz.Orz.2007/2/3. Patrz m.in. B. Dauter, B. Gruszczyński, A. Kabat, M. Niezgódka-Medek, Prawo o postępowaniu przed sądami administracyjnymi. Komentarz, Kraków 2006, (Komentarz do art. 146 p.p.s.a. - LEX), podobnie J. Świątkiewicz, Naczelny Sąd Administracyjny. Komentarz do ustawy, Warszawa 2001, s. 129.

Stanowisko takie zają SN w uchwale z dnia 25.04.1964 r., III CO 12/64, OSPiKA 1965.

S. Breyer, Przeniesienie własności nieruchomości, Warszawa 1976, s. 308 i n. 
Zaznaczyć należy, że w doktrynie poglądy na charakter prawny aktu administracyjnego nie są jednolite. Zgodnie z innym stanowiskiem, akt administracyjny jest aktem zewnętrznym o charakterze konstytutywnym, tworzącym nowy stan prawny $^{29}$. Przyjęcie takiego stanowiska powoduje, że Sąd badając ważność umowy zawartej na podstawie uchylonego aktu administracyjnego, powinien brać pod uwagę przede wszystkim sam fakt uchylenia, a tylko pomocniczo okoliczności, z powodu których uchylenie nastąpiło. Z poglądem takim nie sposób się zgodzić. Przyjęcie takiego stanowiska spowodowałoby konieczność uznania umowy o przyznanie pomocy za swoiste połączenie czynności prawnej cywilnej i aktu administracyjnego, z oczywistą przewagą tego ostatniego. Narusza to podstawową cechę stosunku cywilnoprawnego, nie zapewnia bowiem beneficjentowi środków dostatecznej ochrony, przysługującej mu stosownie do przepisów prawa cywilnego, jako równorzędnemu partnerowi stosunku cywilnego. Ponadto pozbawia sądy powszechne prawa do samoistnego badania ważności czynności cywilnoprawnej.

Spory powstałe pomiędzy stronami dotyczące ważności zawartej umowy i jej wykonania oraz spory o odszkodowanie w związku z bezpodstawną odmową zawarcia umowy są sporami ze stosunków cywilnoprawnych i należą do właściwości sądów powszechnych.

4. Nie wdając się w bardziej szczegółowe rozważania doktrynalne dotyczące charakteru i formy prawnej aktu administracji o odmowie przyznania środków z EFRROW, należy stwierdzić, że procedura ta jest dość skomplikowana i nasuwa szereg wątpliwości w procesie stosowania przepisów ustawy. Szczególnie krytycznie ocenić należy utrzymanie zasad obowiązujących w zakresie odmiennych trybów postępowania w sprawach o przyznanie pomocy przewidzianej w PROW oraz SPO RiMSŻiROW na lata 2004-2006. Konieczne wydaje się zatem sformułowanie postulatu ujednolicenia, uproszczenia i przyspieszenia trybu przyznawania środków, poprzez zastosowanie jednego trybu postępowania dla wszystkich działań w ramach PROW 2007-2013, analogicznego do rozwiązania zastosowanego w przypadku przyznawania środków z funduszy strukturalnych na podstawie ustawy z dnia 6.12.2006 r. o zasadach prowadzenia polityki rozwoju. ${ }^{30}$ Do przewidzianego powołaną ustawą trybu wyłaniania biorców środków publicznych nie stosuje się przepisów k.p.a., z wyjątkiem przepisów dotyczących właściwości miejscowej organów, wyłączenia pracowników organu, doręczeń i wezwań, terminów, udostępniania akt, a także skarg i wniosków. Ustawodawca przewidział w tym zakresie prostszą i szybszą procedurę przyznawania pomocy. Uwagi powyższe dotyczą procedury dofinansowania projektów realizowanych przez beneficjentów, którzy nie są z góry znani, w szczególności beneficjentów spoza sektora finansów publicznych. Tego rodzaju 
projekty wyłaniane są w drodze publicznie ogłaszanego konkursu. Po przeprowadzeniu postępowania konkursowego instytucja organizująca konkurs ogłasza na stronie internetowej listę projektów przewidzianych do dofinansowania oraz informuje każdego z wnioskodawców o wynikach rozpatrzenia jego wniosku. Ustawodawca, realizując postulat szybkości postępowania, przewidział także odrębną procedurę odwoławczą. Wnioskodawca, którego projekt nie został wyłoniony do dofinansowania, w terminie 14 dni od dnia otrzymania informacji w tej sprawie może złożyć pisemny protest rozpatrywany odpowiednio przez instytucję wdrażającą, instytucję pośredniczącą albo instytucję zarządzającą - w przypadkach krajowych programów operacyjnych oraz przez wojewodę - w przypadku regionalnych programów operacyjnych. W przypadku negatywnego rozpatrzenia protestu, wnioskodawca w terminie 7 dni od dnia otrzymania informacji w tym zakresie może skierować wniosek o ponowne rozpatrzenie sprawy do instytucji zarządzającej w przypadku krajowych programów operacyjnych oraz do ministra właściwego do spraw rozwoju regionalnego - w przypadku regionalnych programów operacyjnych. ${ }^{31}$ Jednolitą procedurę konkursową udało się zatem zastosować do wsparcia z funduszy strukturalnych, które udzielane jest na realizację projektów o znacznie większej różnorodności, niż ma to miejsce w przypadku wsparcia z EFRROW.

Ponadto nierozstrzygnięta pozostaje wątpliwość prawna o charakter i formę rozstrzygnięcia o odmowie przyznania środków, poprzedzającego zawarcie cywilnoprawnej umowy. Jeśli jednak przyjmiemy, że ma ono charakter aktu administracyjnego, to istota tego sporu - którą jest możliwość poddania rozstrzygnięcia kontroli sądu administracyjnego - straci na swoim praktycznym znaczeniu. Zarówno akty lub czynności dotyczące uprawnień lub obowiązków wynikających z przepisów prawa, jak i decyzje administracyjne korzystają bowiem z takiego samego poziomu ochrony procesowej. Działanie w obu tych formach może być zaskarżone do sądu administracyjnego, który realizuje kontrolę ich legalności.

Skala wątpliwości interpretacyjnych, jakie wyłaniają się przy zagadnieniach proceduralnych pozyskiwania środków z EFRROW, pozwala na sformułowanie po-

Jednoznacznie rozstrzygnięty został zatem problem niedopuszczalności odwołania od rozstrzygnięcia w sprawie przyznania środków, który zarysował się w okresie obowiązywania poprzedniej ustawy z dnia 20 kwietnia 2004 r. o Narodowym Planie Rozwoju. W ten sposób potwierdzona została poprzednia linia orzecznicza w tym zakresie. Zdaniem sądów działania podejmowane przez instytucje ogłaszające konkurs (m.in. PARP) na etapie oceny wniosków złożonych przez przedsiębiorców nie mają charakteru władczego, a przekazywane przez nie informacje o tej ocenie nie są decyzjami w rozumieniu przepisów k.p.a. Obowiązujace w tym zakresie przepisy wskazuja instytucję zarządzająca (w większości programów Ministra Gospodarki i Pracy) jako organ dokonujący wyboru projektów, którym zostanie udzielone wsparcie. Brak bowiem przepisu prawa przyznającego określonemu podmiotowi prawa uprawnienia do podejmowania decyzji administracyjnych, rozumianych jako oparte na przepisach prawa administracyjnego władcze, jednostronne oświadczenie woli organu administracji publicznej, określające sytuacje prawną konkretnie wskazanego adresata, tak m.in. Postanowienie NSA z 19.03.2003 r. sygn. akt III SA 223/03, postanowienie NSA z 8.12.2003 r. sygn. akt III SA 2835/03, postanowienie WSA w Warszawie z 19.11.2004 r., sygn. akt III SA/Wa 1420/04, wyrok NSA z 24.05.2005 r. sygn. akt II GSK 70/05, postanowienie WSA w Warszawie z 9.06.2005 r., sygn. akt III SA/Wa 782/05, postanowienie WSA w Warszawie z 11.10.2005 r., sygn. akt III SA/Wa 2491/05, postanowienie WSA w Warszawie z 31.03.2006 r., sygn. akt III SA/Wa 2777/05, postanowienie NSA z 24.05.2006 r., sygn. akt II GSK 394/05. 
stulatu o bardziej ogólnym charakterze, dotyczącego wzmocnienia pozycji strony tego postępowania. Jest on szczególnie aktualny w przypadku, gdy beneficjentami pomocy będą rolnicy, prowadzący niewielkie gospodarstwa rolne, którzy wnioskując o środki z funduszu nie będą korzystali z fachowej pomocy w tym zakresie. Postulat ujednolicenia trybu postępowania, uproszczenia, przyspieszenia i obniżenia jego kosztów nie może zostać zrealizowany bez zapewnienia stronom należytej ochrony sądowej. 
Legal character of the act of negative decision on support by the European Agricultural Fund for Rural Development

\section{Summary}

The aim of this paper is an attempt to evaluate selected procedural issues regulated by the Act of 7 March 2007 on support for rural development by the European Agricultural Fund for Rural Development (EAFRD), within the scope of a legal protection of a party to a suit.

This paper deals with two different procedural solutions in cases of support for rural development by the EAFRD. Within the first solution the support is given after the administrative proceedings in particular case and finished by the administrative decision. The other solution is of civil character, which means that the support is granted under the agreement between the Managing Authority and the beneficiary, while the administrative act is the source of the obligation. The main focus of the paper is on the act of negative decision on support by the fund. Its legal character and effects in a civil-legal sphere rise some doubts both in the doctrine as well as in judicial decisions made by different organs of state administration and administrative courts.

The analysis of provisions of the Polish act allows to draw conclusions on a very complicated legal character of the procedure of support for rural development by the European Agricultural Fund for Rural Development. The implementation of the two different procedural solutions, the administrative and the civil ones, should be assessed critically. The unification, simplification and acceleration of the procedure of support for rural development by using one type of procedural solutions for all activities of Rural Development Program of 2007-2013 should be postulated. This postulate, however cannot be realized without providing the parties with adequate legal protection by the administrative court. 